\title{
Mineral Composition of Herbaceous Species Seseli rigidum and Seseli pallasii: a Chemometric Approach
}

\author{
Marija D. Ilić, $1,{ }^{*}$ Violeta D. Mitić, ${ }^{2}$ Snežana B. Tošić, ${ }^{2}$ Aleksandra N. Pavlović, ${ }^{2}$ \\ Marija S. Marković, ${ }^{3}$ Gordana S. Stojanović ${ }^{2}$ and Vesna P. Stankov Jovanović ${ }^{2}$ \\ ${ }^{1}$ Laboratory Sector, Laboratory for Analytical Chemistry, Veterinary Specialized Institute "Niš", \\ DimitrijaTucovića 175, Niš, 18106, Serbia \\ ${ }^{2}$ University of Niš, Faculty of Science and Mathematics, Department of Chemistry, Višegradska 33, Niš, 18000, Serbia \\ ${ }^{3}$ University of Niš, Faculty of Science and Mathematics, Department of Biology and Ecology, Višegradska 33, Niš, 18000, Serbia \\ *Corresponding author: E-mail: marija.fertico@gmail.com \\ Tel.: 0038162365228
}

Received: 05-09-2021

\begin{abstract}
Nutrients play an essential role in many metabolic processes whose deficiency or excess can be harmful to the plant itself and through the food chain to both animals and humans. Medicinal plants used in the food and pharmaceutical industries can be contaminated with increased concentrations of heavy metals. The plant species Seseli rigidum and Seseli pallasii from the Balkan Peninsula are used in traditional medicine and spices in the diet, so it was necessary to determine the mineral composition to ensure their safe application. In this work, the mineral composition was determined in medicinal species of the genus Seseli using inductively coupled plasma with optical emission spectrometry (ICP-OES). Two multivariate statistic methods - principal component analysis (PCA) and hierarchical cluster analysis (HCA) were applied to distinguish samples regarding their mineral composition. The mineral composition of both studied species is following the literature data. The results obtained using multivariate statistics methods agree and distinguish certain parts of the tested plants based on the highest content of micro, macro, or trace elements.
\end{abstract}

Keywords: Sesli rigidum, Seseli pallasii, mineral composition, ICP-OES, multivariate statistics

\section{Introduction}

Almost all metals present in nature can be found in plants. They affect the life processes, anatomical and morphological structure, chemical composition, yield, and prevalence of certain plant species. According to plants' presence, elements can be divided into macro elements, microelements, and trace elements. ${ }^{1}$ Macroelements are structural components of tissues; they have specific functions in the cells and basal metabolism and water and acidic-alkaline balance. ${ }^{2}$ Microelements are needed in much smaller quantities, less than $100 \mathrm{mg}$ per day, making up less than $0.01 \%$ of body mass. Microelements are $\mathrm{Zn}, \mathrm{Fe}, \mathrm{Si}, \mathrm{Mn}, \mathrm{Cu}$, $\mathrm{Cr}$, fluorides, and iodides. Elements primarily present in low quantities (e.g., $\mathrm{Pb}, \mathrm{Cd}, \mathrm{V}$ ) in plants, pose a significant threat to human health when consumed, causing adverse effects and hence, they are categorized as toxic to humans. Therefore, the determination of their content and action mecha- nism has become an area of particular interest and priority in different areas. This classification does not reflect their importance in plant metabolism; only their role is different. Unlike macro elements, microelements act catalytically at low concentrations and are strictly specific. ${ }^{3,4}$

Medicinal plants of the genus Seseli have long been used in traditional medicine in the form of infusion and tinctures. ${ }^{5,6}$ They contain many compounds (essential oils, secondary metabolites) that can preserve good health due to their potential antioxidant, antimicrobial, hepatoprotective, anticancer, and anti-inflammatory activity. ${ }^{7}$ If medicinal plants are applied for pharmacological and veterinary purposes and in humans' and animals' diets, the increased content of individual heavy metals in plants can reduce their therapeutic activity or even be toxic to humans. Therefore, their use is limited. Consequently, the concentration of heavy metals in plants is strictly limited and defined by international standards. ${ }^{8}$ 
Regarding the preceding comments, the primary purpose of this research was to evaluate the contents of elements ( $\mathrm{Al}, \mathrm{B}, \mathrm{Ba}, \mathrm{Ca}, \mathrm{Cd}, \mathrm{Cr}, \mathrm{Cu}, \mathrm{Fe}, \mathrm{K}, \mathrm{Mg}, \mathrm{Mn}, \mathrm{Na}$, $\mathrm{Ni}, \mathrm{Pb}, \mathrm{V}$, and $\mathrm{Zn}$ ) in selected medicinal plants (Seseli rigidum Waldst. \& Kit. and Seseli pallasii Basser), using inductively coupled plasma optical emission spectrometry (ICP-OES).

\section{Experimental}

\section{1. Reagents}

Analytical grade nitric acid $\left(\mathrm{HNO}_{3}\right)$ and $70 \%$ perchloric acid $\left(\mathrm{HClO}_{4}\right)$ supplied from Fischer scientific were used as reagents for the wet digestion of samples. Ultra-scientific (USA) ICP multi-element standard solutions of about $20.00 \pm 0.10 \mathrm{mg} \mathrm{L}^{-1}$ were used as a stock solution for calibration. The containers used for sample storage were cleaned to avoid contamination of the samples with traces of any metal. Containers were treated with $5 \%$ nitric acid and washed with ultra-pure water $18 \mathrm{M} \Omega \mathrm{cm}$ (MicroMed highpurity watersystem, TKA Wasseraufbereitungs systeme $\mathrm{GmbH}$ ).

\section{2 Instrumentation}

All analyses were carried out on aniCAP 6000 inductively coupled plasma optical emission spectrometer (ThermoScientific, Cambridge, United Kingdom), which uses an Echelle optical design and a Charge Injection Device (CID) solid-state-detector. The optimum instrumental conditions are listed in Table 1.

Table 1. Operational parameters for ICP-OES measurements

\begin{tabular}{ll}
\hline Parameters & Values \\
\hline Flush pump rate & $100 \mathrm{rpm}$ \\
Analysispump rate & $50 \mathrm{rpm}$ \\
RF power & $1150 \mathrm{~W}$ \\
Nebuliser gas & $0.71 / \mathrm{min}$ \\
Coolant gas flow & $12 \mathrm{l} / \mathrm{min}$ \\
Auxiliary gas flow & $0.51 / \mathrm{min}$ \\
Plasma view & dual-mode \\
\hline
\end{tabular}

\section{3. The Selection of Analytical Lines}

Before the analysis, spectral lines were selected, spectral interferences and matrix effect in both axial and radial view modes were checked for a total of 44 lines recommended by the ICP OES spectrometer library, which corresponded to 16 identified elements. The analytical lines were selected according to the ratio of the slope of the calibration curve and slope of the standard addition method line (Slope $\left.\mathrm{cal}_{\mathrm{cal}} / \mathrm{Slope}_{\mathrm{sam}}\right)$.

\section{4. Validation}

Based on the calibration curve of each metal, the selected wavelengths of the analyte lines, coefficient of determination, the limit of detection, and limit of quantification are shown in Table 2. The instrument was calibrated at a fourpoint calibration curve. The linearity of each element was tested, ranging from $0 \mathrm{ppm}$ to $5 \mathrm{ppm}$. The calibration curve linearity for each element was evaluated by the coefficient of determination $\left(\mathrm{R}^{2}\right)$. Samples were analyzed in triplicate.

The detection (LOD) and quantification (LOQ) limits were calculated with three and ten times of the blank's standard deviation of the regression line ( $3 \sigma$ and $10 \sigma$ criterion), divided with a slope of the calibration curve. ${ }^{9}$

The spyking method was appled for the recovery test. To each plant sample, $2 \mathrm{ml}$ of element standard solution (containing $62.5 \mathrm{mg} \mathrm{L}^{-1}$ of $\mathrm{Al}, \mathrm{B}, \mathrm{Ba}, \mathrm{Ca}, \mathrm{Fe}, \mathrm{Mg}, \mathrm{Na}$ and $6.25 \mathrm{mg} \mathrm{L}^{-1}$ of $\mathrm{B}, \mathrm{Cd}, \mathrm{Cr}, \mathrm{Cu}, \mathrm{Mn}, \mathrm{Ni}, \mathrm{Pb}, \mathrm{V}, \mathrm{Zn}$ ). The samples were prepared as is described in the section Sample preparation. All experiments were done in triplicate.

\section{5 Plant Material}

Seseli rigidum Waldst. \& Kit. was collected on rocky terrain on the Vidlič Mountain in southeast Serbia in July (the flowering stage) and in September (fruit phase) 2013, while Seseli pallasii Basser was collected in (fruit phase) August 2013 in the area of Kravlje, Serbia. Voucher specimen S. rigidum (No 16447) was deposited in the Herbarium of Botanical Garden "Jevremovac", Faculty of Biology, University of Belgrade, while voucher specimen of $S$. pallasii was deposited in Herbarium of Department of Biology and Ecology, Faculty of Science and Mathematics (HMN), University of Niš (No 7211).

\section{6 Sample Preparation}

Before the analysis, root and aerial vegetative parts (leaf, flower, and fruit) were separated, dried at room temperature. The dried samples were powdered in a stainless steel mill, obtaining fine particles that passed through a 2 $\mathrm{mm}$ mesh and kept in polypropylene pouches for analysis. The wet digestion method of the dried samples was adopted to enable the measurement of the metal concentrations. The metal content in the plant material was determined after the acidic treatment. First, a volume of $10 \mathrm{~mL}$ concentrated $\mathrm{HNO}_{3}$ was added to the sample $(1 \mathrm{~g})$, heated up in the open glass to a small volume (until red vapors originating from $\mathrm{NO}_{2}$ are removed). Digestion was continued with $4 \mathrm{~mL} \mathrm{70 \%} \mathrm{HClO}_{4}$ and again evaporated to a low volume. Finally, the solutions were transferred to standard vessels and diluted to a volume of $25 \mathrm{~mL}$.

\section{7 Data Analysis}

Chemometrics is an interdisciplinary scientific field, which includes multiparametric statistical analysis, math- 
Table 2. Analyte line selected with the ratio Slope $\mathrm{cal}_{\mathrm{cal}} / \mathrm{Slope}_{\mathrm{sam}}$, regression coefficient $\left(\mathrm{R}^{2}\right)$, LOD, LOQ of the calibration for each metal determination, and Recovery values for spiked samples. Plasma view mode: axial.

\begin{tabular}{lcccccc}
\hline Element & $\boldsymbol{\lambda}(\mathbf{n m})$ & Slope $_{\text {cal }} /$ Slope $_{\text {sam }}$ & $\mathbf{R}^{\mathbf{2}}$ & LOD $(\boldsymbol{\mu g} / \mathbf{g})$ & LOQ $(\boldsymbol{\mu g} / \mathbf{g})$ & Recovery $(\%)^{(\%)}$ \\
\hline $\mathrm{Al}$ & 396.152 & 0.976 & 0.99951 & 0.0850 & 0.2802 & 83.3 \\
$\mathrm{~B}$ & 208.959 & 0.987 & 0.99943 & 0.0014 & 0.0051 & 84.3 \\
$\mathrm{Ba}$ & 455.403 & 0.965 & 0.99901 & 0.0272 & 0.0776 & 86.3 \\
$\mathrm{Ca}$ & 317.933 & 0.945 & 0.99992 & 0.0752 & 0.2503 & 94.8 \\
$\mathrm{Cd}$ & 228.802 & 1.056 & 0.99999 & 0.0226 & 0.0756 & 101.2 \\
$\mathrm{Cr}$ & 267.716 & 0.905 & 0.99991 & 0.0610 & 0.2034 & 113.7 \\
$\mathrm{Cu}$ & 224.700 & 1.019 & 0.99993 & 0.0532 & 0.1775 & 111.2 \\
$\mathrm{Fe}$ & 259.940 & 1.011 & 0.99984 & 0.0248 & 0.0502 & 122.2 \\
$\mathrm{~K}$ & 766.490 & 0.984 & 0.99995 & 0.0215 & 0.0846 & 97.7 \\
$\mathrm{Mg}$ & 202.583 & 0.991 & 0.99993 & 0.0584 & 0.1954 & 116.5 \\
$\mathrm{Mn}$ & 257.610 & 0.982 & 0.99995 & 0.0422 & 0.1408 & 97.8 \\
$\mathrm{Na}$ & 589.592 & 1.011 & 0.99999 & 0.0920 & 0.3530 & 112.3 \\
$\mathrm{Ni}$ & 231.604 & 0.983 & 0.9998 & 0.0240 & 0.0678 & 106.5 \\
$\mathrm{~Pb}$ & 220.353 & 0.958 & 0.99998 & 0.0309 & 0.1030 & 115.9 \\
$\mathrm{~V}$ & 311.071 & 0.899 & 0.99904 & 0.0208 & 0.5213 & 97.5 \\
$\mathrm{Zn}$ & 202.548 & 0.981 & 0.99997 & 0.0350 & 0.1168 & 109.7
\end{tabular}

ematical modeling, computer methods, and analytical chemistry. Using mathematical, informational, and statistical methods, it is possible to efficiently and quickly classify compounds and samples into one of the categories. ${ }^{10,11}$

To establish valid mathematical relations, it is necessary to convert all information into numerical ones and then model a mathematical pattern using the basic set of input data obtained experimentally (normalization).

Principal Component Analysis (PCA) is a technique of forming new variables representing combinations of source variables, which allows the extraction of important information and data from the original data sets. By applying PCA, the number of initial data is reduced, and as a result, new so-called variables are obtained- main components (Principal Components, PC). ${ }^{12}$

There are different criteria for determining the required number of components. The Kaiser criterion is most commonly used, according to which all components whose eigenvalue is less than 1 are rejected. ${ }^{13}$ The number of principal components used for further calculations should explain at least $80 \%$ of the total data variance.

HCA is a clustering method that explores the organization of samples in groups and among groups depicting a hierarchy. The result of HCA is usually presented in a dendrogram- plot which shows the organization of samples and their relationships in a tree form. There are two main approaches to resolve the grouping problem in HCA, agglomerative or divisive.

In the first one, each sample is initially considered a cluster, and subsequently, pairs of clusters are merged. In a divisive approach algorithm start with one cluster including all samples, recursive splits are performed. Clustering is achieved using an appropriate metric of samples' distance (Euclidean distance) and linkage criterion among groups. Complete, single, and average, and Ward's linkage is the more common variants of linkage criteria. Based on the optimal value of a target function, Ward's method is a common choice ${ }^{12}$.

All statistical calculations were made using a statistical software package STATISTICA 8.0 (StatSoft, Tulsa, Oklahoma, USA). The datasets were normalized and PCA and HCA were applied to analyze the obtained results.

The following designations were used for the listed parts of plants $S$. rigidum and $S$. pallasii in dendrograms and diagrams: S.r L- S. rigidum Leaf, S.r Fl- S. rigidum Flower, S.r Fr- S. rigidum Fruit, S.r R- S. rigidum Root, S.p L- S. pallasii Leaf, S.p Fl- S. pallasii Flower, S.p Fr- S. pallasii Fruit and S.p R- S. pallasii Root

\section{Results}

Contents of all analyzed metals (Al, B, Ba, $\mathrm{Co}, \mathrm{Cu}, \mathrm{Fe}$, $\mathrm{Mn}, \mathrm{V}, \mathrm{Zn}, \mathrm{Na}, \mathrm{Mg}, \mathrm{Ca}, \mathrm{K}, \mathrm{Cd}, \mathrm{Cr}, \mathrm{Ni}$, and $\mathrm{Pb}$ in $\mathrm{ppm}$ ) in leaf, flower, fruit, and root of the plant species $S$. rigidum and S. pallasii are shown in Figure 1.

\section{1. Microelements (Al, B, Ba, V, Co, Fe, Cu, $\mathrm{Mn}$, and $\mathrm{Zn}$ )}

The concentration of aluminum in S. rigidum ranges from 4.24 to $19.98 \mathrm{ppm}$ and in S. pallasii from 2.75-21.18 ppm.

The lowest concentration of boron was determined in the root of S. rigidum (8.16 ppm), while the highest (13.09 $\mathrm{ppm}$ ) was determined in the fruit. The concentration of boron in S. pallasii ranged from 6.58-22.02 ppm. The highest barium concentration was determined in the root of $S$. rigidum $(4.85 \mathrm{ppm})$, and the smallest in the fruit, $0.96 \mathrm{ppm}$. The barium concentration in $S$. pallasii ranges from 0.47 
$\mathrm{ppm}$ in the root to $2.21 \mathrm{ppm}$ in the leaf. The highest concentrations of cobalt, copper and iron were determined in the root $(5.55,10.98$, and $9.52 \mathrm{ppm}$, respectively). The lowest concentration was found in the leaf of S. rigidum (1.64; 3.99 and $2.30 \mathrm{ppm}$, respectively). Cobalt was determined at the highest level in S. pallasii root (7.14 ppm), while the amount in other parts of the plant is ranged from $2.65 \mathrm{ppm}$ in the leaf to $4.03 \mathrm{ppm}$ in the fruit. The highest amount of iron was determined in the root of $S$. pallasii at $8.83 \mathrm{ppm}$, while the lowest concentration in the leaf is $2.17 \mathrm{ppm}$. The most considerable amount of copper was determined in the reproductive parts of $S$. pallasii- the flower $(7.64 \mathrm{ppm})$ and the fruit $(6.60 \mathrm{ppm})$, while in the root and the leaf were significantly lower (3.34 and $1.83 \mathrm{ppm}$ ). The highest concentration of manganese was recorded in the leaf of $S$. rigidum and S. pallasii ( 8.25 and $8.23 \mathrm{ppm}$ ), while in the root of S. rigidum was significantly lower $(2.73 \mathrm{ppm})$. Vanadium was present in approximately the same concentration in all parts of the investigated plants. In S. rigidum, the highest content was determined in the root $(1.58 \mathrm{ppm})$, the lowest in the fruit (1.49 ppm), while in S. pallasii, it ranges from $1.52 \mathrm{ppm}$ in the leaf up to $1.68 \mathrm{ppm}$ in the root. Zinc content was ranged from 17.80-35.25 ppm in S. pallasii and similarly in S. rigidum ranging from 10.3-37.2 ppm.

\section{2 Macroelements ( $\mathrm{Na}, \mathrm{Mg}, \mathrm{Ca}$, and $\mathrm{K}$ )}

The highest amount of calcium was determined in the leaf of S. rigidum ( $942.68 \mathrm{ppm})$, while a double lower quantity was determined in the root $(467.78 \mathrm{ppm})$. The root of S. rigidum, compared with the other plant's parts, contained deficient potassium and magnesium (775.39 and $958.90 \mathrm{ppm}$ ). In comparison, a significantly higher amount of potassium is determined in the fruit (2949 ppm). The highest concentration of magnesium was determined in the leaf (2284.74 ppm). The sodium content is significantly lower compared to other macroelements determined. An enormous amount of sodium was determined in the fruit and root (85.47 and $81.09 \mathrm{ppm}$ ), while the leaf and flower contain almost the same concentration of this element (52.51 and $53.16 \mathrm{ppm}$ ). The highest potassium content was determined in the fruit of S. pallasii (2279.26 ppm) and the lowest in the root $677.86 \mathrm{ppm}$. The highest sodium concentration was $172.30 \mathrm{ppm}$ in the root and the smallest in the fruit $(32.15 \mathrm{ppm})$. The lowest concentration of magnesium was determined in the root of $S$. pallasii, while in the flower of this plant, the amount of three times higher concentration was determined (15975.98 ppm). The highest concentration of calcium was determined in flower at $1189.86 \mathrm{ppm}$, while the root contains $460.41 \mathrm{ppm}$.

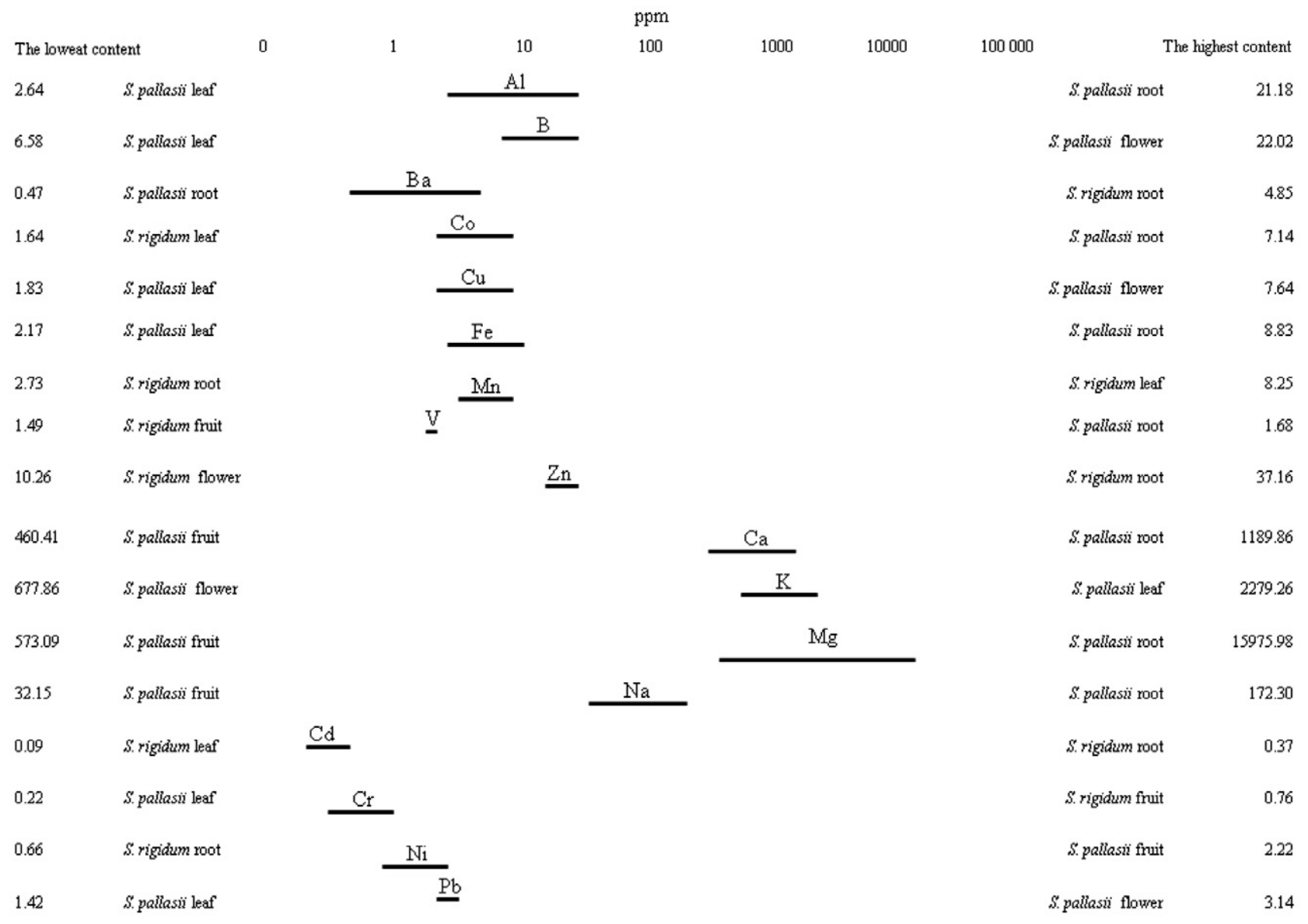

Figure1. Contents of $\mathrm{Al}, \mathrm{B}, \mathrm{Ba}, \mathrm{Co}, \mathrm{Cu}, \mathrm{Fe}, \mathrm{Mn}, \mathrm{V}, \mathrm{Zn}, \mathrm{Na}, \mathrm{Mg}, \mathrm{Ca}, \mathrm{K}, \mathrm{Cd}, \mathrm{Cr}, \mathrm{Ni}$, and $\mathrm{Pb}$ in leaf, flower, fruit, and root of the plant species $\mathrm{S}$. rigidum and S. pallasii 


\section{3 Heavy Metals (Cd, $\mathrm{Cr}, \mathrm{Ni}$, and $\mathrm{Pb})$}

The highest concentration of cadmium was determined at the root of $S$. rigidum $(0.37 \mathrm{ppm})$, while in other parts; the concentration of this heavy metal was significantly lower. The cadmium content in the fruit of S. pallasii $(0.23 \mathrm{ppm})$ is almost two and a half times higher than in the fruit of $S$. rigidum $(0.10 \mathrm{ppm})$. The highest lead content is in the root $(3.11 \mathrm{ppm})$ and the lowest in the flower of $S$. rigidum $(1.87 \mathrm{ppm})$. The highest lead concentration was in flower (3.14 ppm), while it is the lowest in $S$. pallasii leaf (1.42 ppm). The highest chromium concentration was determined in the fruit $(0.76 \mathrm{ppm})$ and the smallest in the leaf $(0.40 \mathrm{ppm})$. The highest chromium concentration was determined in the $S$. pallasii flower $(0.82 \mathrm{ppm})$, while in other parts of the plant, it was significantly lower. The content of nickel in the observed plant species is similar, although a certain amount of $\mathrm{Ni}$ in the fruit of $S$. rigidum $(1.36 \mathrm{ppm})$ is almost twice as large as the fruit of $S$. pallasii, while the content of $\mathrm{Ni}$ in the root of both plant species is almost the same.

\section{Discussion}

The extent of aluminum concentration in analyzed plants of the genus Seseli is slightly lower than in medicinal plants from Serbia's territory. ${ }^{14,15}$ The obtained results show that boron is mobile in the plant and accumulates mainly in the reproductive parts (fruit). The obtained boron concentrations are following 26 herbaceous species boron content from Serbia, ${ }^{14}$ ranged from 5.1-118.7 ppm. The barium content in the plants of the genus Seseli is in the lower concentration range than in the previous research of herbs from Serbia, Turkey, Spain, ${ }^{16}$ Africa, and Asia, as well as in the leaf of Mentha piperitae from Poland. ${ }^{14,16-19}$ Cobalt, copper, and iron are critical biogenic elements responsible for plant growth. Cobalt concentrations in the studied plants are above average concentrations (0.05-0.50 ppm) but still out of critical concentrations (30-40 ppm). ${ }^{7}$ The distribution of copper in vegetative parts of $S$. pallasii is contrary to the corresponding parts of S. rigidum. Average copper concentrations in the plant material are from 3-15 ppm, while the toxic concentration is 20 ppm. ${ }^{7}$ Based on the obtained results for $S$. pallasii and $S$. rigidum, it is evident that the content of the copper is in average concentrations, which is in line with previous studies of medicinal plants. ${ }^{16,17,19-21}$ The typical iron concentration in plants varies from 50-250 ppm, while concentrations above 500 ppm are toxic. ${ }^{7}$ Iron in the analyzed plant species is within a range of average concentrations. In species of the genus Seseli, lower iron content was registered compared to many medicinal and aromatic plants and green and black tea. ${ }^{14,17,20-24}$ The concentration of zinc in both plant species' roots is approximately the same, while in the above-ground parts, it is lower (especially in the flower S. rigidum). Compared with the other observed metals in S. pallasii, zinc was present in higher concentrations. The flower of $S$. pallasii contained the highest concentrations of almost all determined elements compared to other plant parts. ${ }^{25-26}$

Simultaneously, in S. rigidum, the situation is reversed: the highest concentrations of the specified metals are recorded in the root.

Dudić et al. 2007 determined the content of $\mathrm{Mg}$, Ca, $\mathrm{Fe}, \mathrm{Cr}$, and $\mathrm{Ni}$ in the root, stem, and leaf of $\mathrm{S}$. rigidum from different regions, with serpentine (silicate) limestone substrate. $^{27}$ The total content of magnesium was 14150 and $11280 \mathrm{ppm}$ (silicate and limestone), while calcium concentrations were 13500 and $21110 \mathrm{ppm}$ (silicates and limestone). Such a large amount of $\mathrm{Ca}$ and $\mathrm{Mg}$ was explained because the plant $S$. rigidum is tolerant to high concentrations of these metals in the substrate. The plant's mineral composition depends on the leaves' and roots' morphological structure. However, in many cases, the substrate's structure and composition make the results of different studies incomparable since plants are harvested from different geographical areas.

$\mathrm{Ca}$ and $\mathrm{Mg}$ concentrations determined in S. pallasii and S. rigidum ranged in approximately the same range of concentrations. However, in both plant species, the smallest amount of $\mathrm{Ca}$ and $\mathrm{Mg}$ were determined in the root, while the highest concentration of these metals is determined in the above-ground parts and the flower. In all previous studies, the concentration of calcium was significantly higher than in the species of the genus Seseli, ${ }^{18,28}$ while the concentrations of $\mathrm{Mg}$ are comparable with these from the present study. ${ }^{18,21,28}$

In addition to adverse impacts on plants, heavy metals pose a threat to human health due to their persistence in nature. Lead and cadmium are trace elements that are not essential, but they can accumulate in biological systems and become potential contaminants through the food chain. They are toxic for humans, even at low doses. Excessive concentrations of heavy metals inhibit physiological processes such as respiration, photosynthesis, transpiration rates, cell elongation, $\mathrm{N}$-metabolism, mineral nutrition, and biomass decrease and, consequently, can cause plant death. ${ }^{29}$ Accordingly, it is necessary to monitor their even low concentrations in potential sources and, therefore, medicinal herbs. Comparing the obtained results for the heavy metal content $(\mathrm{Cd}$ and $\mathrm{Pb})$ in $S$. rigidum and $S$. pallasii to the prescribed $\mathrm{WHO}$ values ${ }^{30}$, the plants grew in an unpolluted environment are with no increased content of these heavy metals. A certain amount of cadmium and lead in S. pallasii is comparable with these metals' content from the unpolluted environment from Serbia's territory. ${ }^{20}$

Chromium, present in traces, is a necessary metal for a healthy metabolism, and its defiance can cause various disorders both in the plant itself and in consumers. The known fact is that chromium enhances insulin activity. Chromium is relatively evenly distributed in all parts of $S$. rigidum. The concentration of $\mathrm{Cr}$ in $S$. rigidum and $S$. pallasii is within the average concentration of this element. ${ }^{7}$ 
However, it is higher than chromium content in medicinal plants traditionally used in Serbia's alternative medicine. ${ }^{7}$

The amounts of nickel in traces can be helpful in the human organism, especially for enzyme activation, but it can be toxic at higher concentrations. Also, exposure to higher concentrations of nickel causes oxidative stress. The obtained results for both plant species show that the content of nickel is in average concentrations and comparable to the results of analyzed herbs' infusions. ${ }^{7,15}$

\section{1. Statistical Comparison of the Mineral Composition of S. rigidum and S. pallasii}

The multivariate analysis applied to the mineral composition of plants $S$. rigidum and $S$. pallasii includes analysis of the main components (PCA) and hierarchical cluster analysis (HCA).

By PCA analysis, the original variables are converted

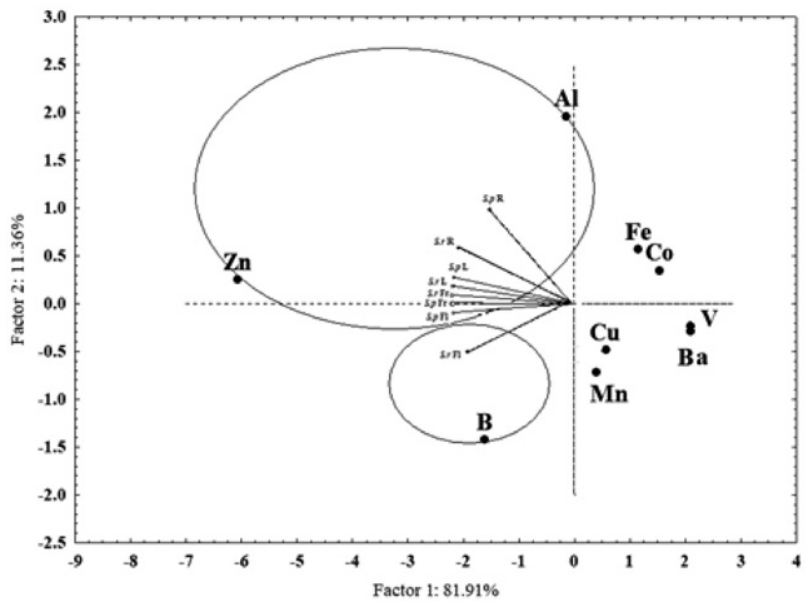

Figure 2. PCA diagram of the variables of the content of microelements (Al, B, Ba, V, Co, Fe, $\mathrm{Cu}, \mathrm{Mn}$, and $\mathrm{Zn}$ ) in the leaf, flower, fruit, and root of plant species $S$. rigidum and $S$. pallasii

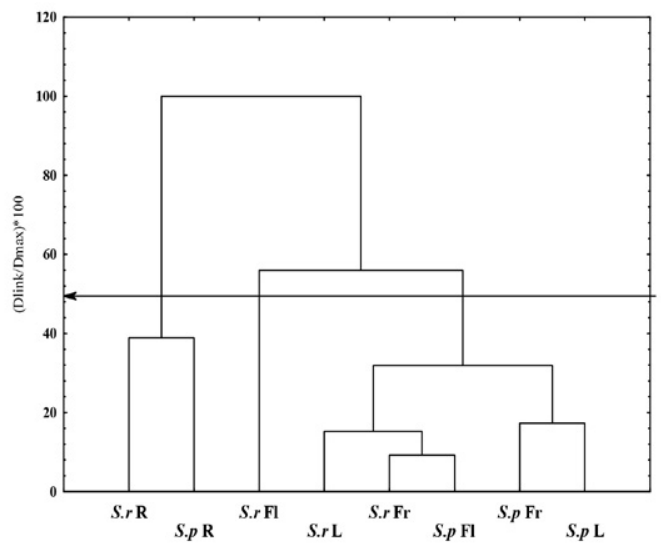

Figure 3. Dendrogram of the microelements content (Al, B, Ba, V, $\mathrm{Co}, \mathrm{Fe}, \mathrm{Cu}, \mathrm{Mn}$, and $\mathrm{Zn}$ ) in the leaf, flower, fruit, and root of plant species $S$. rigidum and $S$. pallasii into new correlation variables, which are called the main components, wherein the first major component explains $81.91 \%$ of the total variability of the mineral composition of $S$. rigidum and $S$. pallasii. The second principal component explains $11.36 \%$, while the third component covers $5.33 \%$ of the total variability.

PCA analysis of S. $p$ R and S. $r$ R variables are isolated concerning other variables, whose clustering is primarily due to aluminum and zinc content. In contrast, S. $r$ Fr is grouped based on the boron content.

The data treated using PCA analysis were subjected to hierarchical cluster analysis (HCA).

Application of HCA analysis to the results of microelements content in the leaf, flower, fruit, and root of the plant species $S$. rigidum and $S$. pallasii concerning the content of microelements ( $\mathrm{Al}, \mathrm{B}, \mathrm{Ba}, \mathrm{V}, \mathrm{Co}, \mathrm{Fe}, \mathrm{Cu}, \mathrm{Mn}$, and $\mathrm{Zn}$ ) in parts (leaf, flower, fruit, and root) of the studied plants are shown in Figure 2.

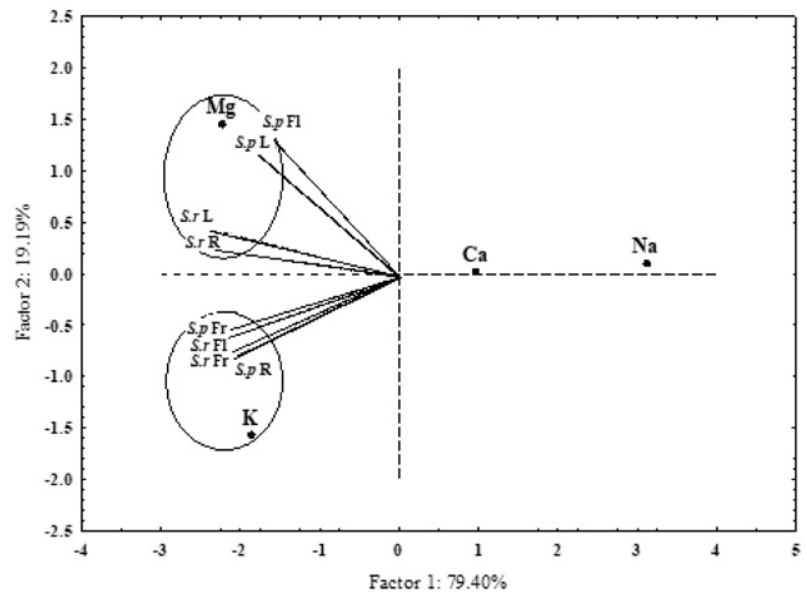

Figure 4. PCA diagram of variables of the macroelements content $(\mathrm{Na}, \mathrm{Mg}, \mathrm{Ca}$, and $\mathrm{K}$ ) in the leaf, flower, fruit, and root of plant species $S$. rigidum and $S$. pallasii

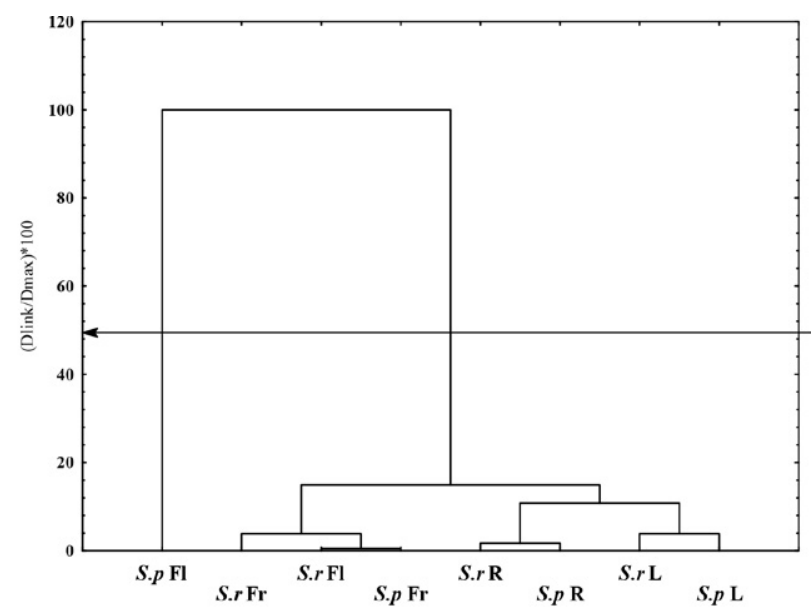

Figure 5. Dendrogram of macroelements content ( $\mathrm{Mg}, \mathrm{Ca}, \mathrm{Na}$ and $\mathrm{K}$ ) in the leaf, flower, fruit, and root of plant species S. rigidum and S. pallasii 
Two statistically significant clusters were obtained based on the cluster analysis of individual parts of plants $S$. rigidum and S. pallasii (Figure 3 ).

Species are grouped because they have significantly higher wrinkle content than the roots of S. rigidum and $S$. pallasii; accordingly, the other cluster can be called a worm cluster.

The cluster analysis separates the underground parts of studied herbs from the above-ground parts based on microelements' content, confirming that the microelements are present in higher concentrations in the root than in the above-ground parts.

The first major component explains $79.40 \%$ of the variance among variables, while the eigenvalue is 6.35 . The second major component explains $19.19 \%$ of the total variance. Together, these two components explain $98.58 \%$ variances. PCA results are illustrated in Figure 4.

Data subjects of PCA analysis were subject to hierarchical cluster analysis (HCA).

Figure 5 shows a dendrogram of macroelements content $(\mathrm{Mg}, \mathrm{Ca}, \mathrm{Na}$, and $\mathrm{K}$ ) in parts of the plants (leaf, flower, fruit, and root) S. rigidum and S. pallasii.

After cluster analysis, two clusters were obtained. S.p $\mathrm{Fl}$ is singled out separately and represents the first cluster, which is in accordance with the highest magnesium content, so the first cluster can be called a magnesium cluster. Within the second cluster, there are two subclasses. The first subclass consists of two sub-clusters, one consisting of S. $p$ L and S. $r$ L (Euclid's distance $=938$ ), and the other S. $p$ R and S. $r$ R (Euclid's distance $=407$ ). In the second subcluster, the plants' reproductive parts were isolated, respectively S.p Fr and S.r Fl (Euclid's distance= 109), most similar in content macroelements. The first subcluster is characterized by the vegetative parts of plants $S$. pallasii and $S$. rigidum that have increased magnesium and potassium content and higher calcium content than the reproductive parts of plants isolated in another subclause characterized by higher potassium content. In general, this cluster can be called potassium clusters.

PCA results are illustrated in Figure 6.

If HCA analysis is applied to the matrix of data used for PCA analysis, the obtained results can be presented with a dendrogram (Figure 7).

The HCA test results for the composition of the heavy metal content $(\mathrm{Cd}, \mathrm{Cr}, \mathrm{Ni}$, and $\mathrm{Pb})$ in the leaf, flower, fruit, and root of the plant species $S$. rigidum and $S$. pallasii are shown in Figure 7.

Based on cluster analysis, three statistically significant clusters were obtained. Within the first cluster, two sub-clusters were singled out. Within the first subclass, the S.p L is grouped, while in the second variant, S.p R, S.p L, S.r Fl, and S.r F. Variants S.r L and S.r Fl are most similar in heavy metals' content (Euclid's distance= 0.17). In $S$. rigidum' fruit, the highest chromium amount was determined concerning other variables within the first cluster. In the second cluster, S. $p$ Fl and S. $r$ R (Euclid's distance=
0.60) were isolated, grouped based on the most abundant lead content and the same cadmium, chromium, and nickel content. In the third cluster, S.p Fr is distinguished because of the higher content of nickel and lead compared to other examined parts of plants $S$. rigidum and S. pallasii.

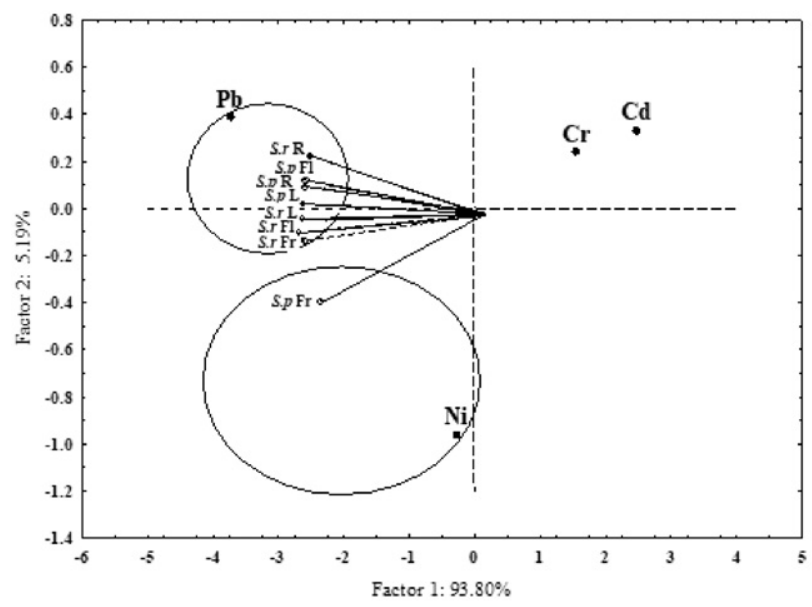

Figure 6. PCA Diagram of heavy metal content $(\mathrm{Cd}, \mathrm{Cr}, \mathrm{Ni}$, and $\mathrm{Pb}$ ) content variables in leaf, flower, fruit, and root of plant species $S$. rigidum and $S$. pallasii

The results obtained with PCA and HCA analysis are in excellent agreement. In the PCA analysis, S. $r$ R was distinguished because it has the most abundant lead content, while on the opposite side of the diagram was S.p Fr because it has a high nickel content (which distinguishes it from other parts of plants), but also significantly lower chromium and cadmium content which was diagonally in the PCA diagram. In the cluster analysis of S. $r$ R and S.p Fl, a flower of $S$. pallasii was found in the same subcluster due to the highest lead content, while S.p Fr was distinguished as a separate cluster due to the higher nickel content than in other examined parts of plants S. rigidum and S. pallasii.



Figure 7. Dendrogram of heavy metals content (Cd, Cr, Ni, and $\mathrm{Pb}$ ) in the leaf, flower, fruit, and root of plant species $S$. rigidum and $S$. pallasii 


\section{Conclusion}

The flower of $S$. pallasii, compared to the other parts of that plant, contains the highest concentrations of almost all of the specified metals, while in the case of S. rigidum, the situation of the different- highest concentrations of the specified metals is recorded at the root. The results obtained for both plant species show that metals' content is within ranges previously reported for the plants from the same area and in the acceptable amounts prescribed by WHO for human consumption.

Both multivariate statistics methods agree and distinguish certain parts of the investigated plants based on the highest content of micro-, macroelement, or heavy metals.

\section{References}

1. K. O. Soetan, C. O. Olaiya, O. E. Oyewole, Afr. J. Food Sci. 2010, 4, 200-222. https://academicjournals.org/article/article1380713863_Soetan\%20et\%20al.pdf

2. B. Imelouane, M. Tahri, M. Elbastrioui, F. Aouinti, A. Elbachiri, J. Mater. Environ. Sci. 2011, 2, 104-111. http://www. jmaterenvironsci.com/Document/vol2/13-JMES-52-2010Emelouane.pdf

3. M. Tuzen, Microchem. J. 2003, 74, 289-297. DOI: $10.1016 / \mathrm{S} 0026-265 \mathrm{X}(03) 00035-3$

4. M. Hoenig, Talanta. 2001, 54, 1021-1038. DOI:10.1016/S0039-9140(01)00329-0

5. J. Matejić, A. Džamić, T. Mihajilov-Krstev, V. Ranđelović, Z. Krivošej, P. Marin, Cent. Eur. J. Biol. 2012, 7, 1116-1122. DOI:10.2478/s11535-012-0094-4

6. K. Skalicka-Wozniaka, R. Losb, K. Glowniaka, A. Malm, Nat. Prod. Commun. 2010. 5, 1427-1430.

DOI: $10.1177 / 1934578 X 1000500916$

7. A. Stanojković-Sebić, R. Pivić, D. Josić, Z. Dinić, A. Stanojković, Tarim. Bilim. Derg. 2015, 21, 317-325.

DOI:10.1501/Tarimbil_0000001334

8. WHO, Library Cataloguing in Publication Data: Quality control methods for medicinal plant materials, World Health Organization Geneva, England, 1998.

9. S. Chandran, S. P. Singh, Pharmazie 2007, 62, 4-14. DOI: 10.1691/ph2007.1.5064

10. S. Wold, Chemometr. Intell. Lab. 1995, 30, 109-115. DOI:10.1016/0169-7439(95)00042-9

11. P. J. Gemperline, Practical Guide to Chemometrics, Taylor \& Francis Group, London, 2006 DOI:10.1201/9781420018301

12. D. Granato, J. S. Santos, G. B. Escher, B. L. Ferreira, R. M. Maggio, Trends Food Sci. Tech. 2018, 72, 83-90.

DOI:10.1016/j.tifs.2017.12.006

13. H. F. Kaiser. Educ. Psychol. Meas. 1960, 20, 141-151.

DOI:10.1177/001316446002000116

14. S. Ražić; A. Onjia; S. Đogo; L. Slavković; A. Popović, Talanta. 2005, 67, 233-239. DOI:10.1016/j.talanta.2005.03.023

15. Ž. A. Mihaljev, M. M. Živkov-Baloš, Ž. N. Ćupić, S. M. Jakšić,
Acta. Pol. Pharm. 2014, 71, 385-391.

DOI:10.2298/HEMIND130424029M

16. P. L. Fernandez-Caceres, M. J. Martın, F. Pablos, A. G. Gonzalez, J. Agr. Food. Chem. 2001, 49, 4775-4779.

DOI:10.1021/jf0106143

17. E. Altintig, H. Altundag, M. Tuzen, B. Chem. Soc. Ethiopia. 2014, 28, 9-16. DOI:10.4314/bcse.v28i1.2

18. A. Moreda-Pineiroa, A. Fisherb, S. J. Hill, J. Food Compos. Anal. 2003, 16, 195-211. DOI:10.1016/S0889-1575(02)00163-1

19. A. Lozak, K. Soltyk, P. Ostapczuk, Z. Fijalek, Sci. Total Environ. 2002, 289, 33-40. DOI:10.1016/S0048-9697(01)01015-4

20. S. Ražić, V. Kuntić, Int. J. Food Prop. 2013, 16, 1-8. DOI:10.1080/10942912.2010.526273

21. S. Basgel, S. B. Erdemoglu, Sci. Total. Environ. 2006, 359, 82 89. DOI:10.1016/j.scitotenv.2005.04.016

22. M. R. Gomez, S. Cerutti, L. L. Sombra, M. F. Silva, L. D. Martinez, Food Chem. Toxicol. 2007, 45, 1060-1064.

DOI:10.1016/j.fct.2006.12.013

23. S. Tokalioglu, Food Chem. 2012, 134, 2504-2508. DOI:10.1016/j.foodchem.2012.04.093

24. A. G. Brudzinka-Kosior, A. Samecka-Cymerman, K. Kolon, L. Mroz, A. J. Kempers, Ecotox. Environ. Safe. 2012, 80, 349354. DOI:10.1016/j.ecoenv.2012.04.005

25. M. Ilić, V. Stankov-Jovanović, V. Mitić, M. Dimitrijević, J. Cvetković, S.Tošić Safe. Eng. 2016, 6, 1-5, DOI:10.7562/SE2016.6.01.01

26. M. Ilić, V. Mitić, M. Marković, S. Ćirić, S. Tošić, G.Stojanović, V. Stankov Jovanović, "XXIII SAVETOVANJE O BIOTEHNOLOGIJI”, Zbornik radova, Čačak, Srbija, 2018, 293-298.

27. B. Dudić, T. Rakić, J. Šininžarar-Sekukulić, V. Atanackovitć, B. Stevanović, Arch. Biol. Sci. 2007, 59, 341-349. DOI:10.2298/ABS0704341D

28. S. Nookabkaew, N. Rangkadilok, J. Satayavivad, J. Agr. Food Chem. 2006, 54, 6939-6944. DOI:10.1021/jf060571w

29. P. Zornoza, S. Vázquez, E. Esteban, M. Fernández-Pascual, R. Carpena, Plant Physiol. Bioch. 2002, 40, 1003-1009. DOI:10.1016/S0981-9428(02)01464-X

30. A. Szymczycha-Madeja, M. Welna, P. Pohl, Microchem. J. 2015, 121, 122-129. DOI:10.1016/j.microc.2015.02.009 


\section{Povzetek}

Hranila igrajo bistveno vlogo v številnih metabolnih procesih, katerih pomanjkanje ali presežek lahko škoduje rastlini sami in prek prehranjevalne verige tudi živalim in ljudem. Zdravilne rastline, ki se uporabljajo v živilski in farmacevtski industriji, so lahko onesnažene z večjimi koncentracijami težkih kovin. Rastlinski vrsti Seseli rigidum in Seseli pallasii z Balkanskega polotoka se uporabljata $\mathrm{v}$ tradicionalni medicini in kot začimbi v prehrani, zato je potrebno določiti mineralno sestavo, da se zagotovi njuna varna uporaba. V tem delu smo mineralno sestavo določili pri zdravilnih vrstah rodu Seseli z uporabo induktivno sklopljene plazme z optično emisijsko spektrometrijo (ICP-OES). Za ločevanje vzorcev glede na njihovo mineralno sestavo sta bili uporabljeni dve multivariatni statistični metodi - analiza glavnih komponent (PCA) in hierarhična skupinska analiza (HCA). Mineralna sestava obeh preučevanih vrst sledi literaturnim podatkom. Rezultati, pridobljeni $\mathrm{z}$ uporabo multivariatnih statističnih metod, se ujemajo in omogočajo diskriminacijo nekaterih delov preizkušenih rastlin na podlagi največje vsebnosti mikroelementov, makroelementov ali elementov v sledovih. 